\title{
Activity of solvent extracts of Prosopis spicigera, Zingiber officinale and Trachyspermum ammi against multidrug resistant bacterial and fungal strains
}

\author{
Rosina Khan ${ }^{1}$, Mohammad Zakir ${ }^{1}$, Sadul H. Afaq ${ }^{2}$, Abdul Latif ${ }^{2}$, Asad U. Khan*1 \\ ${ }^{1}$ Interdisciplinary Biotechnology Unit, Aligarh Muslim University, Aligarh, India \\ ${ }^{2}$ Department of Ilmul Advia, A K Tibbiya College, AMU, Aligarh, India
}

\begin{abstract}
Background: The emerging trends of multidrug resistance among several groups of microorganisms against different classes of antibiotics led different researchers to develop efficient drugs from plant sources to counter multidrug resistant strains. This study investigated different solvent extracts of Prosopis spicigera (P. Spicigera), Zingiber officinale, and Trachyspermum ammi (T. ammi) to determine their efficacy against multidrug resistant microbes.

Methodology: Successive extractions of these plants were performed using a Soxhlet apparatus, using solvents with increasing polarities. Preliminary phytochemical analysis was also performed .Minimum inhibitory concentration was determined by a two-fold serial dilution method followed by determination of minimum bactericidal/fungicidal concentration. Multidrug resistant (MDR) strains of Candida albicans, Candida krusei, Candida tropicalis, Candida glabrata, Escherichia coli and reference strains of Streptococcus mutans and Streptococcus bovis were used in the study.

Results: The ethanolic fraction of $P$. spicigera (least minimum inhibitory concentration [MIC] $-4.88 \mu \mathrm{g} / \mathrm{ml}$ ) demonstrated a remarkable inhibition of the microorganisms while fractions obtained from those of Zingiber officinale (least MIC-78.125 $\mu \mathrm{g} / \mathrm{ml}$ ) exhibited little activity. The petroleum ether fraction of T. ammi (least MIC- $625 \mu \mathrm{g} / \mathrm{ml}$ ) showed best activity when compared to its other fractions. Qualitative analysis of the phytoconstituents was also performed.

Conclusions: The potency shown by these extracts recommends their use against multidrug resistant microorganisms. This study also showed that $P$. spicigera could be a potential source of new antimicrobial agents.
\end{abstract}

Key words: multidrug resistance, ESBLs, plant extracts, bacteria, fungus

J Infect Dev Ctries 2010; 4(5):292-300.

(Received 27 October 2009 - Accepted 14 January 2010)

Copyright (C) 2010 Khan et al. This is an open-access article distributed under the Creative Commons Attribution License, which permits unrestricted use, distribution, and reproduction in any medium, provided the original work is properly cited.

\section{Introduction}

Many efforts have been made to discover new antimicrobial compounds from various kinds of sources such as plants, animals and microorganisms. A large number of plant products have long been utilized as a source of therapeutic agents worldwide [1-3]. Recently, herbal medicines have increasingly been used to treat many diseases including several infections. Plants produce certain chemicals which are naturally toxic to bacteria [4] and many plants have been investigated for the development of novel drugs with therapeutic properties [5]. As opposed to synthetic drugs, antimicrobials of plant origin are not associated with many adverse effects and have an enormous therapeutic potential to heal many infectious diseases.

Drug resistance to pathogenic microorganisms has been commonly reported worldwide. Antibiotic resistance refers to the ability of a microorganism to withstand the effects of an antibiotic. The increasing frequency of microorganisms that are resistant to common and generally accepted antibiotics is on the increase. Furthermore, the rate of resistance to these drugs is higher in developing countries as compared to developed countries because of extensive and indiscriminate use of antibiotics over the last few decades [6] and people's ability to self-medicate without a prescription from a physician. Among the wide array of antibiotics, beta $(\beta)$-lactams are the most varied and widely used [7]. The most common cause of bacterial resistance to $\beta$-lactam antibiotics is the production of $\beta$-lactamases. Bacterial resistance to $\beta$-lactam antibiotics has been attributed to the spread of plasmid-mediated extended spectrum $\beta$ lactamases (ESBLs) [8]. Medicinal plants are natural resources for valuable products that can be used in 
the treatment of various ailments. Plant materials remain an important resource for combating illnesses, including infectious diseases, and many plants have been investigated for novel drugs for the development of new therapeutic agents. Thus the emergence of multiple drug resistance of pathogenic organisms has necessitated a search for new antimicrobial substances from other sources including plants [9].

In the present study, extracts of Prosopis spicigera ( $P$. spicigera), Zingiber officinale ( $Z$. officinale and Trachyspermum ammi (T. ammi), which were prepared using solvents with different polarities, were tested to screen their antimicrobial activity (MIC and minimum bactericidal/fungicidal concentration [MBC/MFC]) against multi-drug resistant Escherichia coli (E. coli, ESBL positive), Candida albicans (C. albicans), Candida krusei ( $C$. krusei), Candida tropicalis (C. tropicalis), Candida glabrata (C. glabrata), Streptococcus mutans ( $S$. mutans) and Streptococcus bovis (S. bovis).

\section{Materials and methods}

\section{Collection and identification of plant materials}

Seeds of T. ammi and dried roots of $Z$. officinale were collected from the local market of Aligarh while the leaves of $P$. spicigera were collected from the campus of Aligarh Muslim University (AMU), Aligarh, India. The taxonomic identities were confirmed by Prof. Wajahat Husain, ex-chairman of the Department of Botany, AMU. The plant materials were washed under running tap water, air dried and then homogenized to fine powder and stored in airtight bottles.

\section{Preparation of extracts}

The powders were refluxed with absolute ethanol for six hours. Successive extraction of these powders was also done with the help of Soxhlet apparatus in different solvents with increasing order of polarity of the solvent. The solvents included petroleum ether, diethyl ether, chloroform, ethyl acetate, acetone, ethanol and methanol. The solvents were evaporated at a constant temperature of $60^{\circ} \mathrm{C}$ until a very concentrated extract was obtained. Identification tests for the various chemicals were conducted to test the presence of different chemical constituents.

\section{Preliminary Phytochemical Analysis}

Qualitative phytochemical screening for various chemical constituents including alkaloids, flavonoids, glycosides, phenols, resins, sugars, amino acids, protein, steroids/terpenes, and tannins were analyzed using the crude extract of $P$. spicigera leaves, $Z$. officinale rhizomes, and T. ammi seeds. Ethanolic fraction of $P$. spicigera, petroleum ether fraction of $T$. ammi, and ethyl acetate fractions of $Z$. officinale were screened for phytochemical constituents as they showed best antibacterial/antifungal activity.

\section{Test for resins}

While gently heating the test solution, acetic anhydride was added to it. After cooling, one drop of sulphuric acid was added. The colour of the solution was observed. A purplish red colour rapidly changing to violet showed the presence of resins $[10,11]$.

\section{Test for alkaloids}

In the test solution, a drop of Dragendorff's reagent (solution of potassium bismuth iodide) was added. Brown precipitate indicated the presence of alkaloids. In the test solution, a drop of Mayer's reagent (potassium tetraiodomercurate solution) was added. A white precipitate showed the presence of alkaloids $[10,11]$.

\section{Test for amino acids}

The ethanolic extract was mixed with ninhydrin solution ( $0.1 \%$ in acetone) and then heated gently in a water bath for a few minutes. A blue to red-violet colour change indicated the presence of amino acids [10].

\section{Test for tannin}

To test for tannin, $10 \%(\mathrm{w} / \mathrm{v})$ ferric chloride solution was added to the extract of the drug. A bluish black colour, which disappeared on addition of dilute sulphuric acid followed by a yellowish brown precipitate, indicated the presence of tannins $[10,11]$.

\section{Test for glycosides}

The extract was hydrolyzed with a few drops of concentrated hydrochloric acid $(\mathrm{HCl})$ and the solution rendered alkaline with a few drops of ammonia solution. Next 5 drops of this solution was added to $2 \mathrm{ml}$ of Benedict's qualitative reagent and boiled. A reddish brown precipitate showed the presence of glycosides [10].

\section{Test for flavonoids}

To the ethanolic extract, concentrated hydrochloric acid $(\mathrm{HCl})$ was added and the colour 
was observed. Red colour indicated the presence of flavonoids. Magnesium ribbon was added to the ethanolic extract of the material followed by the addition of a drop of concentrated hydrochloric acid. A resulting colour ranging from orange to red further confirmed the presence of flavonoids [12].

\section{Tests for sterols/ terpenes}

In the test solution, taken in chloroform, $2 \mathrm{ml}$ of concentrated sulphuric acid was poured from the side of the test tube. The colour of the ring at the junction of the two layers was noted. A red-coloured ring showed the presence of sterols/terpenes. To $1 \mathrm{ml}$ extract, $2 \mathrm{ml}$ of acetic anhydride solution was added, followed by $2 \mathrm{ml}$ of concentrated sulphuric acid. The change in colour was observed. A colour change from red to blue showed the presence of sterols/terpenes [10].

\section{Test for phenols}

In the ethanolic extract, $10 \%(\mathrm{w} / \mathrm{v})$ ferric chloride solution was mixed. A resulting purple or red colour indicated the presence of phenols [10].

\section{Tests for proteins}

In the hot test solution, $1 \mathrm{ml}$ concentrated sodium hydroxide solution was added, followed by one drop of copper sulphate solution. A violet or red colour indicated the presence of proteins. To the test solution, Millon's reagent (Mercury nitrate solution) was added and the colour of the precipitate was observed. A white precipitate showed the presence of proteins $[10,11]$.

\section{Tests for carbohydrate}

To the heated solution of the extract a mixture of equal parts of Fehling's solutions $\mathrm{A}$ and B, previously mixed, was added and heated. The colour of the precipitate was observed. A brickred precipitate of cuprous oxide indicated the presence of reducing sugars. In aqueous solution, $\alpha$-naphthol was added. Afterward, concentrated sulphuric acid was gently poured in. A purple colour ring at the junction of the two solutions indicated the presence of reducing sugars [10].

\section{Test Microorganisms}

The study included multidrug drug resistance (MDR) strains of five ESBL producing strains of $E$. coli (nosocomial infection) confirmed by PCR and seven fungal strains (three strains of $C$. albicans and
C. glabrata, two strains of C. tropicalis, and one strain of $C$. krusei) of vaginal isolates . The strains were isolated, identified and characterized by conventional biochemical methods [1]. Reference strains of S. mutans ATCC-700610 and S. bovis ATCC-9809 were also included in the study. $S$. mutans were grown in Brain Heart Infusion (BHI) Broth (Himedia Labs, Mumbai, India); the rest of the bacteria were grown in Nutrient Broth (Himedia Labs, Mumbai, India) at $37^{\circ} \mathrm{C}$. The yeast cells were grown in Yeast Peptone Dextrose (YPD) Broth (Himedia Labs, Mumbai, India) at $30^{\circ} \mathrm{C}$. The density of microorganisms was adjusted per McFarland 0.5 standard for the experiment.

Determination of minimum inhibitory concentration and minimum bactericidal/fungicidal concentration

The (MIC) and the minimum bactericidal/fungicidal concentration (MBC/MFC) were determined using a broth microdilution method. Stock standard solutions at $20 \mathrm{mg} / \mathrm{mL}$ in ethanol were prepared for all the fractions. Working solutions were prepared by dilution in microplates at concentrations between $5000 \mu \mathrm{g} / \mathrm{mL}$ and $2.44 \mu \mathrm{g} / \mathrm{mL}$ using nutrient medium as the diluent. Ethanol $(50 \mu \mathrm{l})$ was used as control and did not show any inhibitory activity. The bacterial suspensions were added in the wells at the concentration of $10^{5}-10^{6} \mathrm{cfu} / \mathrm{mL}$ (colony forming units $/ \mathrm{mL}$ ). Each inoculum was prepared in its respective medium and density was adjusted to 0.5 Mcfarland standard $\left(10^{8} \mathrm{CFU} / \mathrm{mL}\right)$ and diluted to 1:100 for the broth microdilution procedure. The plates were incubated aerobically at $37^{\circ} \mathrm{C}$ (Candida species at $30^{\circ} \mathrm{C}$ ) for 24 hours. Bacterial and fungal growth was shown by the presence of turbidity in the wells. MICs were determined as the first well in ascending order that did not show any turbidity. To confirm MIC and establish MBC/MFC, $25 \mu \mathrm{L}$ of broth was removed from each well and inoculated on nutrient agar for bacteria and YPD plates for fungal strains. After aerobic incubation at $37^{\circ} \mathrm{C}$ overnight, the highest dilution that yielded no bacterial/fungal growth on solid medium was taken as MBC/MFC. Each experiment was performed in triplicate.

\section{Results}

Results obtained in the present study revealed that the three plant extracts tested possess potential antibacterial activity against multidrug resistant (MDR) E. coli, S. mutans and S. bovis as well as antifungal activity against MDR $C$. albicans, $C$. 
Table 1. Strains used in the study.

\begin{tabular}{|c|c|}
\hline Strain & Description of resistant markers \\
\hline Candida albicans & $\mathrm{It}, \mathrm{Kt}, \mathrm{Fu}$ \\
\hline Candida albican & It, Fu, Cc \\
\hline Candida albicans & It, Kt, Ns,Fu \\
\hline Candida glabrata & It, $\mathrm{Kt}, \mathrm{Fu}$ \\
\hline Candida krusei & It, $\mathrm{Kt}, \mathrm{Fu}, \mathrm{Cc}$ \\
\hline Candida tropicalis & It, Kt, Amp, Fu, Cc \\
\hline Candida tropicalis & It, $\mathrm{Fu}, \mathrm{Cc}$ \\
\hline Escherichia coli & ESBL+ve (TEM-1) \\
\hline Escherichia coli & ESBL+ve (TEM-1) \\
\hline Escherichia coli & ESBL+ve (TEM-1, CTXM) \\
\hline Escherichia coli & ESBL+ve (CTXM) \\
\hline Escherichia coli & ESBL+ve (CTXM) \\
\hline Streptococcus mutans & ATCC-700610 \\
\hline Streptococcus bovis & ATCC-9809 \\
\hline
\end{tabular}

tropicalis, C. glabrata and C. krusie (Table 1). The active fractions found in $P$. spicigera, T.and $Z$. officinale were ethanol, petroleum ether and ethyl acetate, respectively. The crude extracts of the three plants as well as their most active fraction showed positive tests for alkaloids, amino acids, and proteins while none of them exhibited the presence of phenols and flavonoids (Table 2). Tests for resins and reducing sugars were positive only in the case of $Z$. officinale, while $T$. ammi and $Z$. officinale tested positive for sterols and terpenes. Glycosides were found in crude extracts of T. ammi, Z. officinale and in the PE fraction of T. ammi.

When tested for MIC (Table 3), the ethanolic fraction of $P$. spicigera showed significant activity against all the microorganisms with the least MIC being 4.88 $\mu \mathrm{g} / \mathrm{ml}$. The highest antibacterial activity exhibited by this fraction of $4.88 \mu \mathrm{g} / \mathrm{ml}$ was against $S$. bovis and the least activity of $312.5 \mu \mathrm{g} / \mathrm{ml}$ was recorded in two strains of $C$. albicans. The petroleum ether fraction of $T$. ammi showed highest activity against $C$. albicans $(78.125 \mu \mathrm{g} / \mathrm{ml})$ and the lowest in E. coli. Z. officinale ethyl acetate fraction possessed maximum activity against $C$. albicans and $S$. mutans $(625 \mu \mathrm{g} / \mathrm{ml})$. In the majority of the tests, the MBC or MFC (Table 4) was found to be two-fold higher than the MIC. T. ammi exhibited lowest activity to $C$. krusei, E. coli 4 and $S$. bovis whereas $Z$. officinale did not show any inhibitory effect on $C$. albicans $1, E$. coli 3 , or $S$. bovis with $\mathrm{MIC} \geq 5000 \mu \mathrm{g} / \mathrm{ml}$. C. tropicalis 2, E. coli 3 and $S$. bovis were found resistant to P. spicigera.

\section{Discussion}

Plant herbal mixtures have made a large contribution to human health and well-being by providing a source of novel compounds and for the development and synthesis of new chemotherapeutic agents. There exists vast literature on the antiviral, anticariogenic, anthemintic, antibacterial, antifungal, anti-inflammatory and antimolluscal properties of different plants parts [13-17]. Their uses as remedies for many infectious diseases as well as searches for additional substances in plants with antimicrobial activity are frequent [18]. Plants are rich in a wide variety of secondary metabolites, such as tannins, terpenoids, alkaloids, and flavonoids, which have been found in vitro to have antimicrobial properties [19].

T. ammi belongs to the family Umbelliferae and is known as a popular aromatic herb and spice. Its fruit has been used in cooking and as medicine, primarily to control indigestion and flatulence. It is prescribed for colic, diarrhoea, antibacterial and other bowel disorders, and in the treatment of asthma [20]. Z. officinale (family Zingiberaceae) is widely used as a spice, food, and herbal medicine. It is traditionally used for the treatment of rheumatism, nervous diseases, gingivitis, toothache, asthma, constipation, diabetes, and arthritis [21]. It has phytoconstituents that have anti-inflammatory, anti-oxidant and anticancer effects [22,23]. P. spicigera, from the family Leguminosae, is not an extensively studied plant as not much literature is available. It is known to possess anti-inflammatory properties [24]. There are 
Table 2. Qualitative test for various phytochemical constituents in different extracts and fractions.

\begin{tabular}{|c|c|c|c|c|c|c|}
\hline Compound & $\begin{array}{c}P . s . \\
\text { ET extract } \\
\text { (Crude) }\end{array}$ & $\begin{array}{c}T . a . \\
\text { ET extract } \\
\text { (Crude) }\end{array}$ & $\begin{array}{c}\text { Z. } o . \\
\text { ET extract } \\
\text { (Crude) }\end{array}$ & $\begin{array}{c}P . s . \\
\text { ET fraction }\end{array}$ & $\begin{array}{c}T . a . \\
\text { PE fraction }\end{array}$ & $\begin{array}{c}\text { Z. } o . \\
\text { EA fraction }\end{array}$ \\
\hline Alkaloid & $+\mathrm{ve}$ & $+\mathrm{ve}$ & +ve & $+\mathrm{ve}$ & $+\mathrm{ve}$ & $+\mathrm{ve}$ \\
\hline Amino acids & $+\mathrm{ve}$ & +ve & +ve & +ve & +ve & +ve \\
\hline Flavonoids & -ve & -ve & -ve & -ve & -ve & -ve \\
\hline Phenols & -ve & -ve & -ve & -ve & -ve & -ve \\
\hline Proteins & $+\mathrm{ve}$ & +ve & +ve & +ve & +ve & +ve \\
\hline Resins & -ve & -ve & $+\mathrm{ve}$ & -ve & -ve & $+\mathrm{ve}$ \\
\hline $\begin{array}{l}\text { Sterols } \\
\text { terpenes }\end{array}$ & -ve & $+v e$ & $+v e$ & -ve & $+v e$ & $+v e$ \\
\hline $\begin{array}{l}\text { Reducing } \\
\text { sugar }\end{array}$ & -ve & -ve & +ve & -ve & -ve & $+\mathrm{ve}$ \\
\hline Tannins & -ve & -ve & -ve & -ve & -ve & -ve \\
\hline Glycosides & -ve & +ve & +ve & -ve & +ve & -ve \\
\hline
\end{tabular}

P. $s .=$ Prosopis spicigera $;$ T. $a .=$ Trachyspermum ammi Z. $o .=$ Zingiber officinale $; \mathrm{ET}=$ Ethanol; $\mathrm{PE}=$ Petroleum ether $; \mathrm{EA}=$ Ethyl acetate

differences in the antimicrobial activity of the plants in different solvents as each fraction might possess different compounds. This is in agreement with other reports [25,26]. The ability of the extracts to inhibit bacteria as well as fungus suggests the presence of broad spectrum antibiotic compounds. As reported earlier, our study also shows that Gram-positive bacteria are more sensitive than Gram-negative bacteria $[1,27]$.

With the rise in the emergence of various multidrug resistant microorganisms and the scenario worsening through the indiscriminate use of antibiotics, new and/or alternative antimicrobial compounds must be developed to treat common infections. With the changing patterns of susceptibility and the availability of new antimicrobial agents, continuous updating of knowledge concerning treatment of disease caused by such pathogens is required. Extended-spectrum- $\beta$ lactamases (ESBLs) have emerged among Gramnegative bacteria, including Klebsiella pneumoniae (K. Pneumonia) and E. coli, which has greatly contributed to the enhanced resistance toward a wide range of antibiotics that are presently in use. ESBLs include TEM, SHV and CTXM enzymes that are on the rise in enterobacterial isolates $[28,29]$. The search for alternative strategies for the management of disease-resistant microbes is one of the possible strategies towards this objective and involves the rational localization of bioactive phytochemicals which have antibacterial activity. This could be one of the important approaches for the containment of antibiotic resistance [30]. The ability of the plants tested in this study against ESBL-positive bacteria exhibits their efficacy in the treatment of infections caused by such strains.

An alkaloid sceptrin, isolated from Agelas sceptrum, has been shown to possess antimicrobial activity against $S$. aureus, Bacillus subtilis, $C$. albicans, Pseudomonas aeruginosa (P. Aeruginosa), Alternaria (fungus), and Cladosporium cucumerinum [31]. Bromotyrosine alkaloids have demonstrated high antimicrobial activity against a number of Grampositive organisms, including Mycobacteria and Staphylococci, including MRSA, VRSA and VRSH [32]. A number of peptides have also been reported to possess antimicrobial activities. Fallaxin, a 25-mer antibacterial peptide amide, has been shown to inhibit the growth of several Gram-negative bacteria including Enterobacter cloacae, E. coli, $K$. pneumoniae, and P. aeruginosa [33]. Similarly, antimicrobial activities of low molecular mass lysine dendrimers against $S$. aureus, E. coli and C. albicans have been reported earlier [34]. Proteins such as thanatins, upon chemical modification at the sidechain of cysteine residues, exhibited eight-fold higher 
Table 3. MIC $(\mu \mathrm{g} / \mathrm{ml})$ values for different fractions of plant extracts studied against Multi-Drug Resistant strains of fungus and bacteria.

\begin{tabular}{|c|c|c|c|c|c|c|c|c|}
\hline \multirow{2}{*}{ Strain No. } & \multirow{2}{*}{ Plant } & \multicolumn{7}{|c|}{ Fractions } \\
\hline & & $\mathrm{PE}$ & $\mathrm{DE}$ & $\mathrm{CH}$ & EA & $\mathrm{AC}$ & ET & MT \\
\hline \multirow{3}{*}{ C. a. 1} & T. $a$. & 78.125 & 2500 & 2500 & 2500 & 2500 & 1250 & 1250 \\
\hline & Z. o. & 5000 & 5000 & 2500 & 2500 & 2500 & 5000 & 5000 \\
\hline & P.s. & $>5000$ & 5000 & 1250 & 2500 & 1250 & 156.25 & 625 \\
\hline \multirow{3}{*}{ C. a. 2} & T. $a$. & 625 & 625 & 1250 & 1250 & 1250 & 1250 & 1250 \\
\hline & Z. o. & 1250 & 2500 & 1250 & 625 & 1250 & 1250 & 1250 \\
\hline & P.s. & 2500 & 1250 & 1250 & 2500 & 1250 & 312.5 & 1250 \\
\hline \multirow{3}{*}{ C. a. 3} & T. a. & 312.5 & 625 & 1250 & 1250 & 2500 & 2500 & 5000 \\
\hline & Z. o. & 2500 & 625 & 1250 & 1250 & 1250 & 2500 & 5000 \\
\hline & $P . s$. & $>5000$ & 2500 & 2500 & 5000 & 1250 & 312.5 & 1250 \\
\hline \multirow{3}{*}{ C. $g$. } & T. $a$. & 625 & 1250 & 1250 & 2500 & 2500 & 2500 & 5000 \\
\hline & Z. $o$. & 1250 & 2500 & 2500 & 2500 & 2500 & 2500 & 2500 \\
\hline & $P . s$. & 2500 & 5000 & 1250 & 1250 & 1250 & 156.25 & 625 \\
\hline \multirow{3}{*}{ C. $k$. } & T. $a$. & 312.5 & $>5000$ & $>5000$ & 1250 & 2500 & 2500 & $>5000$ \\
\hline & Z. $o$. & 2500 & 5000 & 5000 & 2500 & 2500 & 2500 & 5000 \\
\hline & $P . s$. & 1250 & 2500 & 625 & 1250 & 1250 & 78.125 & 312.5 \\
\hline \multirow{3}{*}{ C.t. 1} & T. $a$. & 625 & $>5000$ & 5000 & 1250 & 1250 & 1250 & 2500 \\
\hline & Z. $o$. & 1250 & 2500 & 1250 & 1250 & 1250 & 2500 & 2500 \\
\hline & $P . s$. & 2500 & 1250 & 2500 & 1250 & 625 & 78.125 & 156.25 \\
\hline \multirow{3}{*}{ C.t. 2} & T. $a$. & 625 & 5000 & 5000 & 1250 & 1250 & 1250 & 2500 \\
\hline & Z. $o$. & 1250 & 2500 & 1250 & 1250 & 1250 & 1250 & 1250 \\
\hline & $P . s$. & 2500 & 2500 & 625 & 2500 & 1250 & 78.125 & 78.125 \\
\hline \multirow{3}{*}{ E. c. 1} & T. $a$. & 1250 & 2500 & 2500 & 2500 & 2500 & 2500 & 5000 \\
\hline & Z. $o$. & 2500 & 5000 & 2500 & 1250 & 625 & 2500 & 5000 \\
\hline & $P . s$. & 2500 & 1250 & 2500 & 2500 & 2500 & 156.25 & 156.25 \\
\hline \multirow{3}{*}{ E. c. 2} & T. $a$. & 2500 & 2500 & 2500 & 2500 & 2500 & 2500 & 2500 \\
\hline & Z. $o$. & 1250 & 2500 & 2500 & 2500 & 1250 & 5000 & 5000 \\
\hline & P.s. & 1250 & 2500 & 1250 & 2500 & 2500 & 78.125 & 312.5 \\
\hline \multirow{3}{*}{ E. с. 3} & T. $a$. & 1250 & 2500 & 1250 & 2500 & 2500 & 2500 & 5000 \\
\hline & Z. o. & 2500 & 5000 & 1250 & 1250 & 5000 & 5000 & 5000 \\
\hline & P.s. & 2500 & 2500 & 5000 & 5000 & 1250 & 1250 & 2500 \\
\hline \multirow{3}{*}{ E.c. 4} & T. $a$. & 1250 & 5000 & 5000 & 2500 & 2500 & 5000 & 2500 \\
\hline & Z. o. & 5000 & 5000 & 1250 & 1250 & 1250 & 1250 & 2500 \\
\hline & P.s. & 1250 & 1250 & 1250 & 2500 & 2500 & 78.125 & 156.25 \\
\hline \multirow{3}{*}{ E. c. 5} & T. $a$. & 1250 & 2500 & 2500 & 2500 & 1250 & 2500 & 2500 \\
\hline & Z. o. & 5000 & 2500 & 2500 & 1250 & 2500 & 2500 & 5000 \\
\hline & $P . s$. & 1250 & 1250 & 1250 & 1250 & 2500 & 78.125 & 156.25 \\
\hline \multirow{3}{*}{ S. $m$. } & T. $a$. & 1250 & 1250 & 1250 & 1250 & 1250 & 1250 & 2500 \\
\hline & Z.o. & 1250 & 1250 & 625 & 625 & 1250 & 1250 & 2500 \\
\hline & $P . s$. & 1250 & 1250 & 1250 & 1250 & 1250 & 9.76 & 625 \\
\hline \multirow[t]{3}{*}{ S. $b$. } & T. $a$. & 625 & 2500 & 5000 & 1250 & 2500 & 2500 & 2500 \\
\hline & Z. o. & 1250 & 2500 & 1250 & 1250 & 1250 & 2500 & $>5000$ \\
\hline & $P . s$. & 2500 & 1250 & 1250 & 2500 & 1250 & 4.88 & 1250 \\
\hline
\end{tabular}

MIC $=$ Minimum Inhibitory Concentration
Strains C. $a .=$ Candida albicans; C. g. = Candida glabrata C. $t .=$ Candida Tropicalis; C. $k .=$ Candida krusei, E.c. $=$ Escherichia coli; S. $m$. $=$ Streptococcus mutans; S. $b .=$ Streptococcus bovis

Plants T. $a .=$ Trachyspermum ammi; Z. o. = Zingiber Officinale; $P$. s. $=$ Prosopis spicigera

Fractions $\mathrm{PE}=$ Petroleum Ether; $\mathrm{DE}=$ Diethyl Ether, $\mathrm{CH}=$ Chloroform, $\mathrm{EA}=$ Ethyl Acetate, $\mathrm{AC} ;=$ Acetone, $\mathrm{ET}=\mathrm{Ethanol} ; \mathrm{MT}=\mathrm{Methanol}$

antimicrobial activity against Micrococcus luteus than wild type thanatin. It was found that there was 
Table 4. MBC/MFC $(\mu \mathrm{g} / \mathrm{ml})$ values for different fractions of plant extracts studied against Multi-Drug Resistant strains of fungus and bacteria.

\begin{tabular}{|c|c|c|c|c|c|c|c|c|}
\hline \multirow{2}{*}{ Strain No. } & \multirow{2}{*}{ Plant } & \multicolumn{7}{|c|}{ Fractions } \\
\hline & & $\mathrm{PE}$ & $\mathrm{DE}$ & $\mathrm{CH}$ & EA & $\mathrm{AC}$ & ET & MT \\
\hline \multirow{3}{*}{ C. a. 1} & T. $a$. & 78.125 & 2500 & 5000 & 2500 & 2500 & 2500 & 1250 \\
\hline & Z. $o$. & $>5000$ & $>5000$ & 2500 & 5000 & 5000 & $>5000$ & $>5000$ \\
\hline & P.s. & $>5000$ & 5000 & 2500 & 5000 & 5000 & 625 & 1250 \\
\hline \multirow{3}{*}{ C. a. 2} & T. $a$. & 625 & 1250 & 2500 & 1250 & 1250 & 5000 & 2500 \\
\hline & Z.o. & 1250 & 2500 & 1250 & 1250 & 2500 & 1250 & 2500 \\
\hline & P.s. & 2500 & 2500 & 2500 & 2500 & 2500 & 312.5 & 1250 \\
\hline \multirow{3}{*}{ C. a. 3} & T. $a$. & 312.5 & 625 & 1250 & 2500 & 2500 & 5000 & $>5000$ \\
\hline & Z.o. & 5000 & 2500 & 1250 & 1250 & 2500 & 2500 & $>5000$ \\
\hline & P.s. & $>5000$ & 5000 & 2500 & $>5000$ & 2500 & 312.5 & 1250 \\
\hline \multirow{3}{*}{ C. $g$. } & T. $a$. & 625 & 2500 & 1250 & 2500 & 5000 & 5000 & $>5000$ \\
\hline & Z. o. & 2500 & 2500 & 5000 & 5000 & 5000 & 2500 & 2500 \\
\hline & $P . s$. & 5000 & $>5000$ & 2500 & 2500 & 2500 & 156.25 & 1250 \\
\hline \multirow{3}{*}{ C. $k$. } & T.a. & 625 & $>5000$ & $>5000$ & 1250 & $>5000$ & 5000 & $>5000$ \\
\hline & Z.o. & 5000 & $>5000$ & $>5000$ & 5000 & 2500 & 5000 & $>5000$ \\
\hline & $P . s$. & 2500 & 2500 & 2500 & 2500 & 2500 & 312.5 & 312.5 \\
\hline \multirow{3}{*}{ C.t. 1} & T. $a$. & 625 & $>5000$ & $>5000$ & 1250 & 2500 & 2500 & 5000 \\
\hline & Z. $o$. & 1250 & 2500 & 1250 & 2500 & 1250 & 5000 & 5000 \\
\hline & $P . s$. & 2500 & 2500 & 2500 & 1250 & 1250 & 312.5 & 625 \\
\hline \multirow{3}{*}{ C.t. 2} & T. $a$. & 1250 & $>5000$ & $>5000$ & 1250 & 5000 & 2500 & 5000 \\
\hline & Z. o. & 2500 & 2500 & 2500 & 2500 & 2500 & 1250 & 1250 \\
\hline & P.s. & 2500 & 2500 & 2500 & 2500 & 2500 & 78.125 & 156.25 \\
\hline \multirow{3}{*}{ E. c. 1} & T. $a$. & 2500 & 5000 & 5000 & 2500 & 5000 & 5000 & $>5000$ \\
\hline & Z. $o$. & 5000 & 5000 & 5000 & 2500 & 2500 & 5000 & $>5000$ \\
\hline & $P . s$. & $>5000$ & 5000 & 5000 & 2500 & 2500 & 312.5 & 312.5 \\
\hline \multirow{3}{*}{ E. c. 2} & T. $a$. & 2500 & 2500 & 5000 & 2500 & $>5000$ & 2500 & 5000 \\
\hline & Z. o. & 2500 & 5000 & 2500 & 2500 & 2500 & $>5000$ & $>5000$ \\
\hline & P.s. & 2500 & 5000 & 2500 & 2500 & 5000 & 156.25 & 625 \\
\hline \multirow{3}{*}{ E.c. 3} & T. $a$. & 2500 & 5000 & 2500 & 2500 & 5000 & 5000 & $>5000$ \\
\hline & Z.o. & 2500 & $>5000$ & 1250 & 2500 & $>5000$ & $>5000$ & $>5000$ \\
\hline & P.s. & 2500 & 5000 & $>5000$ & $>5000$ & 2500 & 2500 & 2500 \\
\hline \multirow{3}{*}{ E. c. 4} & T. $a$. & 2500 & $>5000$ & $>5000$ & 5000 & 2500 & $>5000$ & 5000 \\
\hline & Z. o. & $>5000$ & $>5000$ & 2500 & 2500 & 1250 & 2500 & 2500 \\
\hline & $P . s$. & 2500 & 1250 & 1250 & 2500 & 5000 & 156.25 & 156.25 \\
\hline \multirow{3}{*}{ E. c. 5} & T. $a$. & 2500 & 2500 & $>5000$ & 5000 & 2500 & 5000 & 2500 \\
\hline & Z. $o$. & $>5000$ & 2500 & 2500 & 2500 & 5000 & 5000 & $>5000$ \\
\hline & P.s. & 2500 & 1250 & 1250 & 2500 & 2500 & 78.125 & 156.25 \\
\hline \multirow{3}{*}{ S. $m$. } & T. $a$. & 312.5 & 2500 & 1250 & 2500 & 1250 & 2500 & 2500 \\
\hline & Z. $o$. & 1250 & 1250 & 1250 & 1250 & 2500 & 2500 & 5000 \\
\hline & P.s. & 2500 & 1250 & 2500 & 2500 & 1250 & 9.766 & 625 \\
\hline \multirow[t]{3}{*}{ S. $b$. } & T. $a$. & 1250 & 2500 & 5000 & 1250 & 2500 & 5000 & 2500 \\
\hline & Z. $o$. & 1250 & 2500 & 1250 & 1250 & 2500 & 5000 & $>5000$ \\
\hline & P.s. & 5000 & 2500 & 2500 & 2500 & 1250 & 9.766 & 1250 \\
\hline
\end{tabular}

$\mathbf{M B} / \mathbf{F C}=$ Minimum Bactericidal/Fungicidal Concentration

Strains C. $a .=$ Candida albicans; C. g. = Candida glabrata; C. $t .=$ Candida Tropicalis; C. $k .=$ Candida krusei; E. $c .=$ Escherichia coli; S. $m$. $=$ Streptococcus mutans; S. $b .=$

Plants T. $a .=$ Trachyspermum ammi; $Z$. o. $=$ Zingiber Officinal; $P . s .=$ Prosopis spicigera

Fractions $\mathrm{PE}=$ Petroleum Ether; $\mathrm{DE}=$ Diethyl Ether; $\mathrm{CH}=$ Chloroform; $\mathrm{EA}=$ Ethyl Acetate; $\mathrm{AC}=$ Acetone; $\mathrm{ET}=\mathrm{Ethanol}$; MT = Methanol

an equilateral correlation between antimicrobial activity and side-chain hydrophobicity at the cysteine residues in thanatin [35]. Ginkbilobin, a protein isolated from seeds of Ginkgo biloba, has been reported to exhibit antifungal activity [36]. Protein $\mathrm{C}$ inhibitor (PCI) is a heparin-binding serine proteinase inhibitor belonging to the family of serpin proteins. It shows broad antimicrobial activity against bacterial 
pathogens by inducing membrane disruption followed by the efflux of bacterial cytosolic contents [37]. Antibacterial and antifungal terpenes have been isolated from Pilgerodendron uviferum (D. Don) Florin [38]. A sterol, 7-aminocholesterol displayed antibiotic activity against Saccharomyces cerevisiae, S. aureus, Enterococcus hirae and Bacillus cereus [39]. Iyengaroside-A (2), a glycoside isolated from the ethyl acetate soluble part of the methanolic extract of the marine green alga Codium iyengarii has been reported to show bactericidal activity [40].

The extracts showed significant activity against most of the investigated microbial strains, which is a promising. It is interesting to note that the extracts are not pure compounds and in spite of it, antimicrobial results were obtained, which only suggests the potency of these extracts. The potential for developing antimicrobials from plants is rewarding as it will lead to the development of a phytomedicine to act against microbes. Plant based antimicrobials have enormous therapeutic potential as they can serve the purpose without any adverse effects that are often associated with synthetic compounds; hence isolation and purification of phytoconstituents from these plants may yield significant novel antimicrobials.

\section{Conclusion}

All the extracts showed varying degrees of antimicrobial activity against the resistant strains of microorganisms. The possibility of obtaining phytochemicals was more apparent in the petroleum ether fraction of $T$. ammi, ethyl acetate fraction of $Z$. officinale and ethanol fraction of $P$. spicigera. The presence of phytochemicals may be responsible for their therapeutic effects. These plants could be a source of new antibiotic compounds which could be more effective against multidrug resistant strains of bacteria and fungus. To test and identify the specific antimicrobial compounds, further work is needed.

\section{Acknowledgements}

This work was supported by DST grant no.100/IFD/5160/20072008 and CCRUM grant no. 3-20/2008-CCRUM/EMR to AUK. The author also acknowledges Professor M. Saleemuddin for CIF of this unit. Thanks to Anis and Shazi for providing microbial strains. RK and MZ acknowledge CCRUM for a Senior Research Fellowship.

\section{References}

1. Khan R, Islam B, Akram M, Shakil S, Ahmed A, Ali SM, Siddidui M, Khan AU (2009) Antimicrobial activity of five herbal extracts against multi drug resistant (MDR) strains of bacteria and fungus of clinical origin. Molecules 14: 586-97.

2. Gibbons S (2005) Plants as a source of bacterial resistance modulators and anti-infective agents. Phytochem Rev 4: 6378.

3. Gottlieb OR, Borin MR, Brito NR (2002) Integration of ethnobotany and phytochemistry: dream or reality? Phytochemistry 60: 145-52.

4. Singh B and Bhat TK (2003) Potential therapeutic applications of some antinutritional plant secondary metabolites. J Agric Food Chem 51: 5579-97.

5. Tomoko N, Takashi A, Hiromu T, Yuka I, Hiroko M, Munekazu I, Tsutomu N, Kazuhito W (2002) Antibacterial activity of extracts preparated from tropical and subtropical plants on methicillin-resistant Staphylococcus aureus. J Health Sci 48: 273-76.

6. Akram M, Shahid M, Khan AU (2007) Etiology and Antibiotics Resistance Pattern of Community Acquired Urinary Infections in J N M C Hospital Aligarh India. Ann Clin Microbiol Antimicrob 6: 4.

7. Bronson JJ, Barrett JF (2001) Quinolone, Everninomycin, Glycylcycline, Carbapenem, Lipopeptide and Cephem Antibacterials in Clinical Development. Curr Med Chem 8: 1775-93.

8. Sanders CC and Sanders WE Jr (1987) Clinical importance of inducible beta-lactamases in gram-negative bacteria. Eur J Clin Microbiol 6: 435-38.

9. Lin RD, Chin YP, Lee MH (2005) Antimicrobial activity of antibiotics in combination with natural flavonoids against clinical extended-spectrum beta-lactamase (ESBL)producing Klebsiella pneumoniae. Phytother Res 19: 61217.

10. Evans WC (2002) Trease and Evan's Pharmacognosy. 15th edition. Elsevier Science Limited. pp.156-336.

11. Afaq, SH, Tajuddin, Siddiqui, MMH (1994) Standardization of Herbal Drugs. AMU Press, Aligarh. pp. 93-94, 143-46.

12. Fornasworth WR (1966) Biological and phytochemical screening of plants. J Pharma Sci 55: 225.

13. Islam B, Khan SN, Naeem A, Sharma V, Khan AU (2008) Novel Effect of Plant Lectins on the Inhibition of Streptococcus mutans Biofilm Formation on Saliva-coated Surface. J Applied Microbiol 160: 1682- 89.

14. Islam B, Khan SN, Haque I, Alam M, Mushfiq M, Khan AU (2008) Novel anti-adherence activity of Mulberry Leaves: Inhibition of Streptococcus mutans Biofilm by 1Deoxynojirimycin isolated from Morus alba. J Antimicrob Chemother 62: 751-57.

15. Stepanovic S, Antic N, Dakic I, Svabicvlahovic M (2003) In vitro antimicrobial activity of propilis and antimicrobial drugs. Microbiol Res 158: 353-57.

16. Govindarajan R, Vijayakumar $M$, Singh $M$, Rao CHV, Shirwaikar A, Rawat AKS, Pushpangadan P (2006) Antiulcer and antimicrobial activity of Anogeissus latifolia. J Ethnopharmacol 106: 57-61.

17. Betoni JEC, Mantovani RP, Barbosa LN, Di-Stasi LC, Fernandes A (2006) Synergism between plant extract and antimicrobial drugs used on Staphylococcus aureus diseases. Mem Inst Oswaldo Cruz 101: 4.

18. Lewis K and Ausubel FM (2006) Prospects for plant-derived antibacterials. Nat Biotechnol 24: 1504-07.

19. Norman J (1990) The Complete Book of Spices. Dorling Kindersley Ltd, London, 6-40 
20. Kaur GJ, Arora DS (2009) Antibacterial and phytochemical screening of Anethum graveolens, Foeniculum vulgare and Trachyspermum ammi. BMC Complement Altern Med 9: 30.

21. Chang CP, Chang JY, Wang FY, Chang JG (1995) The effect of Chinese medicinal herb Zingiberis rhizoma extract on cytokine secretion by human peripheral blood mononuclear cells. J Ethnopharmacol 48: 13-19.

22. Isa Y, Miyakawa $\mathrm{Y}$, Yanagisawa M, Goto T, Kang MS, Kawada T, Morimitsu Y, Kubota K, Tsuda T (2008) 6Shogaol and 6-gingerol, the pungent of ginger, inhibit TNF$\alpha$ mediated downregulation of adiponectin expression via different mechanisms in 3T3-L1 adipocytes. Biochem Biophys Res Commun 373: 429-34.

23. Ippoushi K, Azuma K, Ito H, Horie H, Higashio H (2003) [6]-Gingerol inhibits nitric oxide synthesis in activated J774.1 mouse macrophages and prevents peroxynitriteinduced oxidation and nitration reactions. Life Sci 73: 3427-37.

24. Madan BR, Godhwani JL, Dadhich AP, Soni RK, Ghosal SK, Mahatma OP (1972) Phytochemical, pharmacodynamic and anti-inflammatory properties of Prosopis spicigera stem bark. Indian J Physio pharmacol 16: 145-50.

25. Parekh J, Karathia N, Chanda S. (2006) Evaluation of antibacterial activity and phytochemical analysis of Bauhinia variegate L. bark. Afr J Biomed Res 9: 53-56.

26. Parekh J, Jadeja S, Chanda S (2005) Efficacy of Aqueous and Methanol Extracts of Some Medicinal Plants for Potential antibacterial Activity. Turkish J Bio 29: 203-10.

27. Buwa LV, Staden JV (2006) Antibacterial and antifungal activity of traditional medicinal plants used against venereal diseases in South Africa. J Ethnopharmacol 103: 139-42.

28. Mushtaq S, Woodford N, Potz N (2003) Detection of CTXM-15 extended-spectrum b-lactamase in the United Kingdom. J Antimicr Chemother 52: 528-29.

29. Shakil S, Ali SZ, Akram M, Ali SM, Khan AU (2009) Risk factors for ESBL producing $E$. coli and $K$. pneumonia acquisition in a neonatal care unit. $J$ Trop Pediatr. In press.

30. Bonnet R (2003) Growing group of extended-spectrum blactamases: the CTX-M enzymes. Antimicrob Agents Chemother 48: 1-14.

31. Soltis PA, Soltis DE, Chase MW (1999) Angiosperm phylogeny inferred from multiple genes as a tool for comparative biology. Nature 402: 402- 404.

32. Pick N, Rawat M, Arad D, Lan J, Fan J, Kende AS, Av-Gay $\mathrm{Y}$ (2006) In vitro properties of antimicrobial bromotyrosine alkaloids. J Med Microbiol 55: 407-15.
33. Nielsen SL, Frimodt-Møller N, Kragelund BB, Hansen PR (2007) Structure--activity study of the antibacterial peptide fallaxin. Protein Sci 16: 1969-76.

34. Janiszewska J, Urbańczyk-Lipkowska Z (2006) Synthesis, antimicrobial activity and structural studies of low molecular mass lysine dendrimers. Acta Biochim Pol 53: 77-82.

35. Orikasa Y, Ichinohe K, Saito J, Hashimoto S, Matsumoto K, Ooi T, Taguchi S (2009) The hydrophobicity in a chemically modified side-chain of cysteine residues of thanatin is related to antimicrobial activity against Micrococcus luteus. Biosci Biotechnol Biochem 73: 1683-84.

36. Miyakawa T, Sawano Y, Miyazono K, Hatano K, Tanokura M (2007) Crystallization and preliminary X-ray analysis of ginkbilobin-2 from Ginkgo biloba seeds: a novel antifungal protein with homology to the extracellular domain of plant cysteine-rich receptor-like kinases. Acta Crystallogr Sect F Struct Biol Cryst Commun 63: 737-39.

37. Malmström E, Mörgelin M, Malmsten M, Johansson L, Norrby-Teglund A, Shannon O, Schmidtchen A, Meijers JC, Herwald H (2009) Protein C inhibitor- a novel antimicrobial agent. PLoS Pathog 5: 1-11.

38. Solís C, Becerra J, Flores C, Robledo J, Silva M (2004) Antibacterial and antifungal terpenes from Pilgerodendron uviferum (D. Don) Florin. J Chil Chem Soc 49: 157-161.

39. Dherbomez M, El kihel L, Letourneux Y (1995) Antibacterial activity of 7-aminocholesterol, a new sterol. FEMS Microbiol Lett 126: 91-92.

40. Ali MS, Saleem M, Yamdagni R, Ali MA (2002) Steroid and Antibacterial Steroidal Glycosides from Marine Green Alga Codium Iyengarii Borgesen. Nat Prod Lett 16: 407-13.

\section{Corresponding author}

Asad U. Khan

Interdisciplinary Biotechnology Unit

Aligarh Muslim University

Aligarh, 202002 India

Phone: 0091-571-2720388

Fax: 0091-571-2721776

Email: asad.k@rediffmail.com

Conflict of Interests: No conflict of interests is declared. 